EETP Vol. 16, 2021, №. 2(60)

ISSN 1896-2327 / e-ISSN 2353-7787

DOI: $10.35765 /$ eetp.2021.1660.05

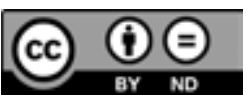

Nadesłano: 2.01.2021

Zaakceptowano: 16.02.2021

Sugerowane cytowanie: Kos E.A. (2021). Specyfika kształcenia nauczycieli wczesnej edukacji w Finlandii i Estonii. Podobieństwa i różnice, „Edukacja Elementarna w Teorii i Praktyce", vol. 16, nr 2 (60), s. 65-76. DOl: 10.35765/eetp.2021.1660.05

\title{
Specyfika kształcenia nauczycieli wczesnej edukacji w Finlandii i Estonii. Podobieństwa i różnice
}

\section{Specific Characteristics of Educating Early School Teachers in Finland and Estonia. Similarities and Differences}

\section{SŁOWA KLUCZE ABSTRAKT}

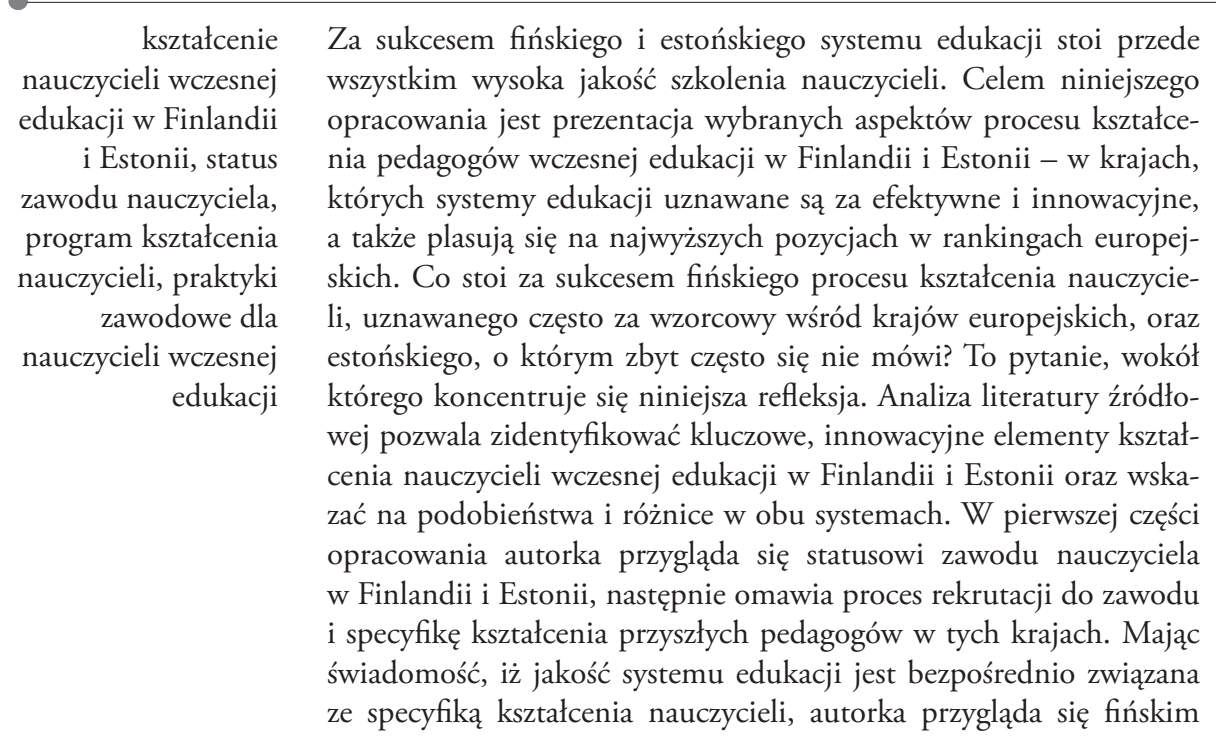


i estońskim programom studiów i stara się wydobyć te elementy, które uważa za wyróżniające się. Szczegółowo omawia specyfikę praktyk zawodowych oraz inicjatywę roku zawodowego.

\section{KEYWORDS ABSTRACT}

education of early school teachers in Finland and Estonia, status of the teaching profession, teacher training curriculum, internship for early school teachers
High quality of teacher training is the main reason for the success of the Finnish and Estonian education systems. The aim of this study is to present selected aspects of the process of teaching early school educators in Finland and Estonia - the countries in which education systems are effective, innovative and rank highest in European analyses concerning schools. What is the secret of the success of Finnish teacher education, often considered a benchmark among European countries; and of the Estonian system of teacher training, which is hardly ever mentioned? This is the question on which this work is focused. The analysis of sources makes it possible to identify key innovative elements of teacher education in Finland and Estonia, and to show similarities and differences in both systems. In the first part of the article, the author analyses the status of the teaching profession in Finland and Estonia, and then she discusses the recruitment process and the specific characteristics of teacher training systems in these countries. Taking into account that the quality of the education system is directly related to the specific nature of teacher education, the author studies the Finnish and Estonian curricula of studies, and tries to find some elements that can be considered outstanding. Also, she discusses in detail the specific characteristics of student internship and the initiative of the professional year.

\section{Wprowadzenie}

Jednym z porównawczych badań, na podstawie którego można stawiać wnioski na temat jakości kształcenia w różnych krajach na świecie, jest Program Międzynarodowej Oceny Umiejętności Uczniów (PISA). Badanie realizowane jest co 3 lata we wszystkich krajach członkowskich OECD, a także w kilkudziesięciu innych krajach. Przyglądając się wynikom tychże badań na przestrzeni ostatniej dekady, można zauważyć, iż uczniowie z Estonii wypadają w tym badaniu coraz lepiej (w 2018 r. Estonia wypadła najlepiej pośród krajów europejskich, uzyskując największą liczbę punktów w pomiarze wszystkich umiejętności, które obejmuje PISA). Uczniowie z Finlandii najwyższe wyniki uzyskali w roku 2009, w latach następnych ich notowania systematycznie spadają, jednak nadal utrzymują się w europejskiej czołówce. Od tamtej pory szuka się jednak wyjaśnień i przyczyn leżących u podstaw sukcesu Finlandii 
w międzynarodowych ocenach porównawczych. Według opinii publicznej, można to jednoznacznie przypisać aktywności fińskich nauczycieli, uznawanych za znakomitych, oraz wysokiej jakości fińskiego kształcenia nauczycieli.

Obecnie Estonia także jest jednym z wiodących krajów w dziedzinie edukacji i jak wspomniano, wyprzedziła Finlandię w wynikach oceny PISA. Z tego względu warto przyjrzeć się wybranym aspektom procesu przygotowania do zawodu nauczyciela w tych dwóch krajach.

Niniejsza praca nie może być traktowana jako całościowa i szczegółowa analiza porównawcza systemów kształcenia nauczycieli w obu krajach. Doniosłość zagadnienia, a zwłaszcza jego wielowymiarowość, potrzebowałyby zdecydowanie bardziej wyczerpującego opracowania. Pomimo tego autorka zdecydowała się na poruszenie zagadnienia w formie artykułu naukowego, mając nadzieję, iż przedstawione w nim tezy będą stanowić impuls do powstania następnych opracowań.

\section{Status zawodu nauczyciela w Finlandii i Estonii - uwarunkowania socjokulturowe}

Zawód nauczyciela w Finlandii jest związany w wysokim prestiżem społecznym, wyższym niż w większości innych rozwijających się krajów europejskich. Wydaje się, iż istotnym czynnikiem mającym wpływ na ten stan rzeczy miało wyjątkowo wytrwałe dążenie tej grupy zawodowej do profesjonalizmu. Już w 1890 roku nauczyciele uczący w szkołach podstawowych twierdzili, że ich kształcenie powinno być organizowane na poziomie uniwersyteckim, a w okresie drugiej wojny światowej w Finlandii było więcej nauczycieli szkół podstawowych po egzaminie maturalnym niż w jakimkolwiek innym kraju europejskim. Istotnym przełomem w podniesieniu statusu i prestiżu zawodu nauczyciela było uruchomienie Uniwersyteckiego Kolegium Pedagogicznego w Jyväskylä w latach trzydziestych XX wieku, i trzech kolejnych, które rozpoczęły swoje funkcjonowanie po II wojnie światowej. Były to pierwsze instytucje, znacznie przewyższające w hierarchii edukacyjnej seminaria dla nauczycieli. W końcu lat pięćdziesiątych XX wieku coraz aktywniej działał związek nauczycieli, który dążył do tego, aby kształcenie nauczycieli szkół podstawowych odbywało się na poziomie uniwersyteckim (Simola 2005).

W Estonii nauczyciele są szanowani, jednak ich prestiż nie jest aż tak wysoki jak w Finlandii. Na szczeblu ministerialnym wciąż wdrażane są działania, aby podnosić rangę zawodu nauczyciela, zwiększyć zainteresowanie wykonywaniem tego zawodu wśród absolwentów szkół średnich i zatrzymać pedagogów już pracujących. Warto nadmienić, iż średni wiek estońskich nauczycieli jest jednym z najwyższych w porównaniu z innymi krajami OECD, a udział młodych, aktywnych zawodowo nauczycieli 
jest jednym z najniższych w Europie. Władze Estonii wciąż czynią starania, aby zwiększać atrakcyjność zawodu nauczyciela wśród młodych osób (między innymi nieustannie podnosząc wartość wynagrodzenia za pracę i dostosowując je do wkładu pracy i wyników uzyskiwanych przez nauczyciela - w Estonii dąży się do tego, aby zrównać przeciętne wynagrodzenie nauczycieli z poziomem średniej pensji specjalisty z wykształceniem wyższym) i podnosić poczucie bezpieczeństwa zawodowego nauczycieli (https://novaator.err.ee/586347/milline-peaks-olema-nuudisaegne-opetajakoolitus; https://www.hm.ee/et/tegevused/opetaja-ja-koolijuht).

\section{Proces rekrutacji do zawodu nauczyciela w Finlandii i Estonii}

Jak wspomniano, szacunek Finlandczyków dla pracy nauczycieli ma głębokie korzenie historyczne i jest niezwykle ważną cechą kulturową fińskiego społeczeństwa. W Finlandii nie brakuje kandydatów do zawodu nauczyciela. Obecnie łatwiej jest dostać się na wydział prawa czy medycyny na Uniwersytecie w Helsinkach niż na wydział pedagogiki i program kształcenia nauczycieli edukacji wczesnoszkolnej. $\mathrm{Na}$ Uniwersytecie w Helsinkach przyjmowanych jest na ten program mniej niż 10\% kandydatów (Tirri 2014). Właśnie ta popularność zawodu nauczyciela wśród fińskich uczniów może być uznana za wyraźny wskaźnik wysokiego statusu zawodu nauczyciela w społeczeństwie.

W Finlandii kandydaci do zawodu wybrani są na podstawie ich predyspozycji akademickich oraz kompetencji komunikacyjnych i społecznych (Tirri 2014). Do programu kształcenia nauczycieli edukacji wczesnoszkolnej trafiają więc wyróżniający się uczniowie. Członkowie zespołów rekrutujących mają jednak świadomość, że nie zawsze tak jest, iż najlepsi uczniowie okazują się dobrymi nauczycielami. Docenia się również tych kandydatów, którzy mieli trudności w nauce, oni bowiem potrafią zrozumieć swoich uczniów najlepiej i wykazać się pełną troski postawą empatyczną.

Krajowy system selekcji do zawodu nauczyciela w Finlandii składa się z następujących etapów:

1. Ogólnokrajowy egzamin mający na celu rozpoznanie i dokonanie oceny umiejętności uczenia się kandydata, które potrzebne są na studiach pedagogicznych.

2. Test umiejętności akademickich (badający m.in. umiejętności pisania, wypowiadania się) odbywający się w formie rozmowy kwalifikacyjnej opartej na materiale pisemnym przekazanym kandydatom 20 minut przed rozmową. Podczas rozmowy ocenia się także predyspozycje do zawodu nauczyciela (motywację do podjęcia studiów, umiejętności interakcji oraz prezentacji własnych opinii i poglądów związanych z tekstem) (Niemi, Jakku-Sihvonen 2011: 43). 
W Estonii brane są pod uwagę dwa główne kryteria wyboru kandydatów na nauczycieli edukacji wczesnoszkolnej. Są to wyniki w nauce oraz cechy osobowe kandydata (poziom umiejętności interpersonalnych, komunikacyjnych i współpracy). Aby je ocenić, zespół egzaminacyjny obserwuje kandydatów w toku wykonywania ćwiczeń w grupach (Eisenschmidt 2011: 116).

\section{Organizacja procesu kształcenia nauczycieli w Finlandii}

Fińskie szkolenie nauczycieli jest wysoko cenione w porównaniach międzynarodowych (Kaljuve 2010: 67). Ramy organizacji procesu kształcenia nauczycieli w Finlandii wciąż się zmieniają, a uniwersytety w Finlandii mają dużą autonomię w projektowaniu swoich programów nauczania. W rezultacie nie ma jednego szczegółowego programu kształcenia nauczycieli dla wszystkich uniwersytetów. Jednak instytucje kształcące nauczycieli przestrzegają pewnych zasad i ogólne zarysy programów są wspólne (Tirri 2014).

Nauczyciele w fińskich placówkach przedszkolnych są zobowiązani do posiadania uniwersyteckiego lub politechnicznego tytułu licencjata w dziedzinie pedagogiki lub kwalifikacje, które określano niegdyś jako policealne kwalifikacje zawodowe. Nauczyciele na poziomie przedszkolnym są nauczycielami wychowania przedszkolnego albo nauczycielami kształcenia zintegrowanego. Nauczyciele uczący w klasach I-VI szkoły powszechnej są na ogół nauczycielami kształcenia zintegrowanego i posiadają tytuł magistra pedagogiki (https://eurydice.org.pl/wp-content/uploads/2014/10/finlandia.pdf).

Celem studiów pedagogicznych na finlandzkich uczelniach jest tworzenie możliwości uczenia się interakcyjnego. Ważne jest, aby student miał świadomość tego, jak rozwija się jego umiejętność nauczania, planowania procesu edukacyjnego, oceniania podejmowanych treści pod kątem zgodności z programem nauczania, potrzeb społeczności szkolnej, możliwości uczniów. Nadrzędnym celem studiów jest więc wsparcie studentów w dążeniu do zdobycia profesjonalnych umiejętności dydaktycznych i ukształtowanie postawy badacza, który będzie potrafił racjonalnie ocenić realizowany przez siebie proces nauczania, a ponadto będzie umiał krytycznie zastanowić się nad swoją praktyką i umiejętnościami społecznymi (Nemi, Jakku-Sihvonen 2011:38-42).

W ramach procesu bolońskiego programy kształcenia nauczycieli edukacji przedszkolnej, szkół podstawowych (i nie tylko) zostały zreformowane na wszystkich fińskich uniwersytetach. Dokonując przeglądu podstawowych elementów studiów pedagogicznych na 12 wydziałach kształcenia nauczycieli na fińskich uniwersytetach, można wskazać 4 główne elementy. Najważniejszym jest praktyka pedagogiczna. Drugim niezwykle ważnym obszarem kształcenia przyszłych nauczycieli są studia w zakresie kształtowania kompetencji badawczych. Trzecim jest teoria i historia wychowania. 
Największy obszar merytoryczny studiów w większości programów nauczania stanowi dydaktyka, psychologia wychowawcza, socjologia edukacji, filozofia edukacji, historia edukacji i edukacja porównawcza ${ }^{1}$.

Te komponenty wzajemnie na siebie oddziaływają, a przez ich strukturę, od początku do końca programu studiów, przenika podejście oparte na badaniach, które jest zintegrowane z każdym szczegółowym kursem objętym w programie. Przedmioty z zakresu metod badawczych są wprowadzane na samym początku studiów, a ich uwieńczeniem jest napisanie pracy magisterskiej (Tirri 2014). Celem jest kształtowanie postawy badacza wśród przyszłych nauczycieli. Wdrażane więc od wielu lat na fińskich uniwersytetach strategie kształcenia nauczycieli promują rolę nauczyciela jako badacza. Z tego względu kursy metodologii badań stanowią integralną część programów kształcenia i doskonalenia nauczycieli (Kaljuve 2010: 68).

W literaturze fińskiej postrzega się tę postawę jako bliską refleksyjności orientację na dociekanie (Jyrhämä, Maaranen 2012). Nauczyciel postrzegany jest bowiem jako ten, który bada, zauważa i próbuje rozwiązać trudności zaobserwowane podczas zajęć. Ma umiejętność oceniania skuteczności swoich działań i aktualizowania strategii nauczania na podstawie wyników uzyskiwanych przez uczniów. Jest na bieżąco ze znajomością literatury naukowej, szczególnie raportów z badań edukacyjnych. Potrafi wykorzystywać wyniki badań naukowych jako wytyczne w swojej pracy (Kaljuve 2010: 68). Jest świadomy i kwestionuje założenia, wartości, które wnosi do procesu nauczania. Dostrzega kontekst instytucjonalny i kulturowy, w którym naucza. Chętnie podejmuje wysiłki i działania na rzecz zmiany szkoły i bierze odpowiedzialność za własny rozwój zawodowy (Jyrhämä i Maaranen 2012: 109).

Warto nadmienić, iż wyróżniającą się cechą programów kształcenia nauczycieli w wielu krajach europejskich jest kształtowanie postawy badacza. Działania zmierzające do kształtowania tejże postawy są coraz częściej wdrażane również w Estonii (Kansanen 1999: 51). Dodatkowo w Estonii mocno akcentuje się konieczność ciągłego doskonalenia nauczycieli (http://www.opetajateliit.ee/wp-content/uploads/2018/06/ Lisa4_\%C3\%95petaja-meistriklassi-kontseptsioon.pdf).

\section{Główne elementy programów kształcenia nauczycieli wczesnej edukacji w Estonii}

Zmiany w zakresie programów kształcenia nauczycieli w Estonii w ostatnich latach były bardzo podobne do tych w Finlandii. W przypadku programów kształcenia

\footnotetext{
1 W Finlandii istnieje kilka ośrodków doskonalenia nauczycieli, zatem w programach nauczania na różnych uniwersytetach kładzie się akcent na inny obszar kształcenia, np. edukację obywatelską, medialną, wychowanie muzyczne, wychowanie fizyczne, wychowanie zdrowotne (Kaljuve 2010:70).
} 
nauczycieli w Estonii, podobnie jak w Finlandii, takimi kluczowymi elementami są zdobywanie teoretycznej wiedzy (podstawowa wiedza teoretyczna obejmuje szkolenie m.in. z dydaktyki, psychologii wychowawczej, socjologii edukacji, filozofii wychowania, historii wychowania, pedagogiki porównawczej), rozwój umiejętności badawczych i praktyka pedagogiczna (Harva 1960, za: Kansanen 1999: 51).

Estońskie programy nauczania dużą ilość czasu przeznaczają na studia z zakresu dydaktyki ogólnej i metodyki przedmiotowej. Priorytetem jest więc rozwijanie u przyszłych nauczycieli umiejętności nauczania (Kansanen 1999: 58-63). Podobnie jak $\mathrm{w}$ finlandzkich programach kształcenia nauczycieli, bardzo istotnym aspektem kształcenia w Estonii jest rozwijanie u studentów umiejętności badawczych. Program studiów obejmuje metodologię badań, a także wszystkie inne kursy związane z umiejętnościami badawczymi oczekiwanymi od nauczycieli w momencie zatrudnienia (warto nadmienić, iż w Estonii mniej czasu poświęca się na rozwijanie umiejętności badawczych niż w Finlandii, więcej czasu przeznacza się natomiast na studiowanie dydaktyki ogólnej i metodyk przedmiotowych) (Kansanen 1999: 58).

Przyglądając się programowi kształcenia nauczycieli w Estonii, warto zwrócić uwagę na jego mocne strony. Ma on strukturę modułową. Jest wszechstronnym, a zarazem logicznie uporządkowanym, dobrze zintegrowanym pięcioletnim cyklem kształcenia nauczycieli. Nie jest stałym konstruktem, lecz jego twórcy nieustannie go dopracowują, modyfikują, systematycznie reagując na zapotrzebowanie rynku pracy i zmiany zachodzące w społeczeństwie. Jego głównym celem jest kształtowanie u uczestników postawy świadomego, zorientowanego na dziecko podejścia do procesu uczenia się.

Program kształcenia nauczycieli składa się z następujących modułów:

- Przedmioty ogólnouczelniane,

- Przedmioty związane z wybraną specjalnością pedagogiczną,

- Dydaktyka,

- Edukacja, wychowanie i psychologia szkolna,

- Praktyka pedagogiczna,

- Podstawy badań naukowych,

- Język obcy,

- Przedmioty fakultatywne,

- Seminarium magisterskie.

W toku przedmiotów z modułu ogólnouczelnianych studenci poznają m.in. podstawy psychologii i filozofii. Mają możliwość zdobywania doświadczeń związanych $\mathrm{z}$ uczeniem się $\mathrm{w}$ interdyscyplinarnym zespole. Warto nadmienić, iż jednym z obowiązkowych przedmiotów tego modułu jest tzw. ELU - ehk Erialasid Lóimiv Uuendus . To innowacyjny przedmiot, w ramach którego studenci różnych dyscyplin, wspólnie z opiekunami, realizują projekty we współpracy z otoczeniem społecznym. 
Celem przedmiotów w ramach kolejnego modułu jest przygotowanie merytoryczne nauczycieli wczesnej edukacji do wdrażania określonych treści nauczania (realizowane są przedmioty takie jak m.in. edukacja polonistyczna, edukacja matematyczna, edukacja społeczno-przyrodnicza, edukacja informatyczna, edukacja artystyczna, edukacja zdrowotna).

Przedmioty w ramach modułu dydaktycznego bezpośrednio przygotowują do tworzenia warsztatu pracy nauczyciela. Wspierają rozwój wiedzy i podstawowych umiejętności planowania, analizowania przebiegu zajęć dydaktycznych.

Zajęcia z zakresu modułu wychowania i psychologii szkolnej stwarzają możliwość poznania teoretycznych i empirycznych podstaw prawidłowości uczenia się i rozwoju dziecka. Ponadto przedmioty z tego modułu rozwijają krytyczne myślenie i umiejętność autoanalizy.

Praktyki pedagogiczne, wspierające rozwój kompetencji zawodowych, są częściowo zintegrowane ze studiami teoretycznymi. Odbywają się w każdym roku akademickim i zazwyczaj poza uczelnią. Przedmioty rozwijające kompetencje badawcze studentów pomagają zrozumieć zasady prowadzenia badań naukowych. W Estonii akcentuje się konieczność kształtowania u nauczycieli wczesnej edukacji postawy samodzielnego i etycznego badacza (o czym wspomniano w poprzedniej części opracowania).

$\mathrm{Na}$ estońskich uniwersytetach priorytetem jest także kształtowanie umiejętności posługiwania się językiem obcym. Od nauczycieli oczekuje się sprawności w zakresie rozumienia literatury obcojęzycznej i komponowania profesjonalnych tekstów w języku obcym. W ramach modułu przedmiotów fakultatywnych student ma możliwość wyboru przedmiotów, które go najbardziej interesują, a są prowadzone przez specjalistów z różnych uniwersyteckich jednostek organizacyjnych. Na koniec studiów każdy z przyszłych nauczycieli zobowiązany jest opracować pracę magisterską (https://www. pedagogicum.ut.ee/et/opetajakoolitus/alusmoodul).

\section{Specyfika praktyki pedagogicznej w toku i bezpośrednio po ukończeniu studiów w Finlandii i Estonii}

Warto nadmienić, że mocną stroną fińskiego systemu kształcenia nauczycieli jest jego naukowy charakter i wszechstronność. Niezwykle istotnym jego elementem jest praktyka pedagogiczna. Wyznaczają ją dwie podstawowe zasady: student powinien rozpocząć praktykę jak najwcześniej, praktyka musi być zintegrowana ze studiami teoretycznymi. Praktyka przebiega w kilku fazach. Początkowo student jest obserwatorem swojego opiekuna, prowadzi obserwację życia szkoły i uczniów z perspektywy edukacyjnej. Z czasem studenci biorą na siebie obowiązki związane z nauczaniem, a nauczyciele wspierają ich $w$ tych działaniach. W Finlandii ten ostatni okres jest 
zwykle ściśle powiązany z badaniami naukowymi prowadzonymi w ramach pracy magisterskiej (Nemi, Jakoo 2011: 44-45).

Według ekspertów ds. edukacji nauczycieli, sekretem sukcesu fińskiego systemu kształcenia nauczycieli są właśnie praktyki, staże w tzw. szkołach praktycznych. Są to szkoły partnerskie działające na wszystkich uniwersytetach, które służą głównie jako baza staży i praktyk (Kaljuve 2010: 67). Wydaje się, iż to właśnie te szkoły, zapewniając wszechstronne wsparcie uniwersytetom, mają największy wpływ na kształcenie nauczycieli. Kierownictwo tychże szkół, jak i większość nauczycieli w nich zatrudnionych, są otwarci na współpracę z uczelniami, upatrując w tym przestrzeni do rozwoju szkoły. Między uczelniami a szkołami partnerskimi, które są równorzędnymi partnerami w opracowaniu koncepcji praktyk, stażu, szkoleń dla studentów, buduje się relacja zaufania. Wykładowcy akademiccy są też zaangażowani w nauczanie w szkołach i doskonale znają ich specyfikę (https://opleht.ee/2015/05/ koolitegelikkusega-seotud-opetajaharidus/).

W Estonii praktyka pedagogiczna jest ściśle związana z przedmiotami z modułu podstawowego. Jej zadaniem jest wspieranie - poprzez obserwację i praktykę w rzeczywistym środowisku uczenia się - tego, czego student uczy się w teorii.

Udział praktyk w estońskich programach kształcenia nauczycieli wzrósł w ostatniej dekadzie, a powiązanie między teorią a praktyką jest coraz lepsze. Zrezygnowano z podejścia, aby najpierw kształtować wiedzę, a następnie umiejętności praktyczne. Studenci studiów pedagogicznych zaraz po rozpoczęciu studiów odbywają praktyki w szkole, aby ćwiczyć i rozwiązywać problemy praktyczne. Fundamentem jest zintegrowanie praktyki i teorii oraz upowszechnienie tej pierwszej na cały okres studiów (https://www.ajakiri.ut.ee/artikkel/911).

Dbałość uniwersytetów o jakość praktyk w szkołach jest na podobnym poziomie w Finlandii i Estonii. Liczba godzin praktyk w Estonii, która w porównaniu z wieloma innymi krajami europejskimi jest zdecydowanie wyższa, jest formalnie jednak nieco niższa niż w Finlandii. Warto jednak nadmienić, iż wiele zadań wykonywanych podczas toku studiów na estońskich uniwersytetach wymaga działania w środowisku pracy nauczyciela, czyli przede wszystkim w szkole (Kansanen 1999: 58). Tego rodzaju starania zwiększają realnie liczbę godzin działań praktycznych studentów w środowisku edukacyjnym estońskich studentów.

W skład modułu praktyk na estońskich uniwersytetach wchodzi ciągła praktyka pedagogiczna, staż ciągły, praktyka podstawowa, praktyka pedagogiczna na uczelni.

Ciągła praktyka pedagogiczna odbywa się pomiędzy pierwszym a trzecim semestrem studiów. W każdym semestrze student przebywa 4-5 dni w placówce stażowej, gdzie wykonuje zadania obserwacyjno-ćwiczeniowe, które koncentrują się przede wszystkim na zagadnieniach podejmowanych w ramach przedmiotów z modułu podstawowego (stanowią one podstawę rozwoju ogólnych kompetencji pedagogicznych). 
W placówce stażowej studenci kształcą się pod kierunkiem nauczyciela-mentora, którego głównym zadaniem jest prowadzenie systematycznych dyskusji mentoringowych (dodatkowo już na pierwszym etapie studiów pozwala się studentom obserwować lekcje i w niewielkim zakresie włączać się w ich prowadzenie). Na uczelniach regularnie odbywają się także spotkania podsumowujące pracę studentów w placówce.

Praktyka może także przyjąć formułę stażu ciągłego. Staż odbywa się w III semestrze studiów, ma przeważnie formę stażu obserwacyjno-partycypacyjnego, związanego zwykle z określonym przedmiotem. W ramach tego stażu odbywają się również wizyty grupowe studentów w placówkach edukacyjnych. Opiekunem stażu w instytucji jest mentor, który umożliwia studentowi obserwację lub samodzielne zrealizowanie części lekcji. W toku stażu wspiera, prezentuje swoją pracę, a w razie potrzeby udziela informacji zwrotnej na temat działań studenta.

Praktyka podstawowa (główna) odbywa się na przestrzeni III i IV semestru studiów. Nie jest bezpośrednio związana z określonym przedmiotem studiów. To dłuższy staż zawodowy, który daje studentowi sposobność zweryfikowania tego, czego nauczył się w toku studiów. Opiekun w placówce umożliwia obserwację lekcji, wspiera w przygotowaniu i przeprowadzeniu lekcji, czy innego działania edukacyjno-wychowawczego. Analizuje wraz ze studentem ich przebieg, udziela informacji zwrotnej na temat lekcji, następnie dokonuje pisemnej oceny zajęć studenta na zakończenie praktyki. W przypadku programów, w których istnieje możliwość wyboru dodatkowej specjalności, odbywa się również praktyka specjalistyczna, której formuła jest taka sama, jak praktyki głównej.

W toku praktyki pedagogicznej prowadzonej na uczelni, która realizowana jest w II i III semestrze studiów, studenci planują, a następnie prowadzą tzw. mini-lekcje dla swoich kolegów (Trasberg, Krul 2015: 80; https://www.pedagogicum.ut.ee/et/ opetajakoolitus/opetajakoolituse-kutseopingud).

Warto nadmienić, że analiza literatury wskazuje na to, iż najsłabszym ogniwem kształcenia nauczycieli w Finlandii jest brak oferty efektywnego wsparcia, mentoringu dla początkujących nauczycieli. Nie został stworzony przejrzysty model mentoringu, brakuje jasnej struktury, koncepcji, reguł, podstawowych zasad koordynacji. Ponadto jego dostępność zależy od aktualnie realizowanej polityki regionalnej lub aktywności dyrektora szkoły (Kaljuve 2010: 67, 70-72).

W Estonii dość prężnie rozwijana jest idea tzw. roku zawodowego, który postrzegany jest jako pomost między odebraną wiedzą w toku studiów a ustawicznym rozwojem zawodowym początkującego nauczyciela. Celem tej idei (rocznego stażu) jest wsparcie procesu adaptacji nauczyciela do zawodu i szkoły, w której został zatrudniony, a także dalszy rozwój umiejętności zawodowych nabytych w toku studiów. Jest to program wprowadzany na szczeblu krajowym, a każdy rozpoczynający pracę nauczyciel ma obowiązek w nim uczestniczyć. 
Wsparcie początkującego nauczyciela obejmuje współpracę z mentorem, którym jest inny, bardziej doświadczony pracownik, a także możliwość udziału w grupie wsparcia (https://www.hm.ee/et/tegevused/opetaja-ja-koolijuht/koolitus-ja-arendustegevus; https://www.riigiteataja.ee/akt/122032011015).

\section{Zakończenie}

Fiński i estoński system kształcenia, uznawane za efektywne i innowacyjne, plasują się na najwyższych pozycjach w rankingach europejskich systemach edukacji. Za ich sukcesem kryją się systematycznie wdrażane reformy obejmujące modyfikacje $\mathrm{w}$ zakresie programu nauczania, decyzje administracyjne o charakterze infrastrukturalnym, finansowym i oczywiście dydaktyczno-wychowawczym. Jakość systemów edukacji w Finlandii i Estonii jest jednak bezpośrednio związana ze specyfiką kształcenia nauczycieli w tych krajach oraz warunkami pracy, jakie są oferowane tej grupie zawodowej.

\section{Bibliografia}

Eisenschmidt E. (2011). Teacher education in Estonia, w: ed. Valenčič Zuljan M., Vogrinc J., European Dimensions of Teacher Education -Similarities and Differences, Ljubljana: Dravska tiskarna.

Jouko K.; Nikkanen P., Jouko K., Tapani K. (1999). Through Education into the World of Work. Uno Cygnaeus, the Father of Technology Education, Institute for Educational Research Jyvaskyla: University of Jyvaskyla.

Jakku-Sihvonen R., Tissari V., Ots A., Uusiautti S., Voolma H. (2010). Soome ja Eesti aineōpetaja óppekavade pedagoogiliste ópingute öppesisu profilide vôrdlusuuring, w: Opetaja esmaharidus Olukord ja probleemid 21. sajandi algul, Koostajad Viive-Riina Ruus Ene-Silvia Sarv, Tallinn: Vali Press OÜ, s. 48-66.

Kaljuve M. (2010). Suundumused Soome ópetajahariduses, w: Opetaja esmaharidus Olukord ja probleemid sajandi algul, Koostajad Viive-Riina Ruus Ene-Silvia Sarv, Tallinn: Vali Press OÜ, s. 67-75.

Tirri K. (2014). The last 40 years in Finnish teacher education, „Journal of Education for Teaching", 40 (5), s. 600-609.

Trasberg K., Krul E. (2015). Opetajahariduse sajand rahvusülikoolis, www. Pedagogicum Tartu Ülikooli ópetajahariduse uuendamiselojs.utlib.ee [dostęp: 03.11.2020].

Niemi H., Jakku-Sihvonen R. (2011). Teacher education in Finland, w: ed. Valenčič Zuljan M., Vogrinc J., European Dimensions of Teacher Education - Similarities and Differences, Ljubljana: Dravska tiskarna.

Niemi H. (2015). Teacher Professional Development in Finland: Towards a More Holistic Approach, Psychology, „Society \& Education”, 7(3), s. 279-294. 
Olli-Pekka M., Pertti V., Hannu S. (2012). Teacher education in Finland: a review of a national effort for preparing teachers for the future, "The Curriculum Journal”, 23(4), s. $567-584$.

Simola H. (2005). The Finnish miracle of PISA: historical and sociological remarks on teaching and teacher education, „Comparative Education”, 41 (4), s. 455-470.

\section{Netografia}

https://pisa.ibe.edu.pl/ [dostęp: 09.10.2020]

http://www.opetajateliit.ee/wp-content/uploads/2018/06/Lisa4_\%C3\%95petaja-meistriklassi-kontseptsioon.pdf [dostęp: 10.10. 2020]

www.eesti.pl/system-edukacyjny-estonii-11947.html [dostęp: 10.12.2020]

https://novaator.err.ee/586347/milline-peaks-olema-nuudisaegne-opetajakoolitus [dos-

tęp: 09.10.2020]

https://www.hm.ee/et/tegevused/opetaja-ja-koolijuht [dostęp: 09.10.2020]

https://eurydice.org.pl/wp-content/uploads/2014/10/finlandia.pdf [dostęp: 10.12.2020]

https:/www.pedagogicum.ut.ee/et/opetajakoolitus/alusmoodul [dostęp: 09.10.2020]

(https://opleht.ee/2015/05/koolitegelikkusega-seotud-opetajaharidus/ [dostęp:

04.11.2020]

https:/www.pedagogicum.ut.ee/et/opetajakoolitus/opetajakoolituse-kutseopingud [dos-

tęp: 05.10.2020]

https://www.ajakiri.ut.ee/artikkel/911 [dostęp: 07.10.2020]

https://www.hm.ee/et/tegevused/opetaja-ja-koolijuht/koolitus-ja-arendustegevus [dostęp:

09.10.2020]

https://www.riigiteataja.ee/akt/122032011015 [dostęp: 10.11.2020]

\section{ADRES DO KORESPONDENCJI}

Ewa Arleta Kos

Uniwersytet Łódzki

Wydział Nauk o Wychowaniu

Katedra Badań Edukacyjnych

e-mail: ewa.kos@now.uni.lodz.pl 